Çoban O., Üstündaĝ E., Çoban A. (2015). The Structural Analysis Of Construction Sector Of Turkey And Its Effect On The Selected Macroeconomic Indicators. Copernican Journal of Finance \& Accounting, 4(1), 27-44. http://dx.doi.org/10.12775/CJFA.2015.002

\author{
OrHAN ÇOBAN* \\ Selcuk University, Department of Economics \\ EMINE ÜSTÜNDAĜ́ ${ }^{* *}$ \\ Selcuk University, Department of Economics
}

Ayşe ÇOBAN ${ }^{* * *}$

Selcuk University, Vocational School of Social Sciences

\title{
THE STRUCTURAL ANALYSIS OF CONSTRUCTION SECTOR OF TURKEY AND ITS EFFECT ON THE SELECTED MACROECONOMIC INDICATORS
}

Keywords: construction sector, economic indicators, Turkey.

J E L Classification: L74.

Abstract: In this study the Turkish construction sector was structurally considered and the effect of sector on some selected macroeconomic indicators was analyzed. In this scope, besides the statistical indicators, the linkages of sector with the other sectors were handled. As a result of evaluations, the construction sector affects the national income significantly. There is a high level correlation between the growth of

Date of submission: April 10, 2015; date of acceptance: May 7, 2015.

* Contact information: ocoban@selcuk.edu.tr, Selcuk University, Department of Economics, Konya, Turkey, phone: +905362265270.

** Contact information: emine.ustundag@vicat.com.tr, Selcuk University, Department of Economics, Konya, Turkey, phone: +905449652020.

${ }^{* * *}$ Contact information: acoban@selcuk.edu.tr, Selcuk University, Vocational School of Social Sciences, Konya, Turkey, phone: +905301485830 . 
construction sector and the growth of national income. In this scope, while the construction sector grows in higher rates, in the periods, when the economic growth actualizes; in the crisis periods, it downsizes in the higher rates. When the figures of employment are taken into consideration the employment of main construction sector increases with every passing day. Depending on development of foreign constructing services, the positive effect of construction sector on the Balance of Payments becomes more important with every passing year. When the backward and forward linkages of sector are considered, it was identified that the forward linkages are weaker than the backward linkages.

\section{IIIINTRODUCTION}

Construction sector is one of the most important sectors in terms of socioeconomic developments of countries. It includes especially housing, construction of every kind of construction such as school, factory, workplace, and hospital; every kind of infrastructure activity such as construction of bridge and dam; and all equipment works such as electricity, water, sanitary installation, heating, and air conditioning. Within this scope, presenting the place and importance of sector in the country economy; its linkages with production related sectors and the level of these linkages; the share in national income of itself and sectors it is in relationship with, and its effect on employment and Balance of Payments have significance.

Construction sector, due to have a close relationship with other sectors, is accepted as one of the leading and driving sectors. The concept of inter-sectorial relationship was first included in the literature by Hirschman (1958). In this scope, construction sector, with its both forward and backward linkages, affects other sectors in economy. Thus, changes in the construction sector also concern the social welfare in the axis of economic growth. According to Keynesian theory, investment - at least building investments - plays important role in the total demand and economic growth in the short run. The studies carried out point out that in terms of the intensity of inter-sectorial relationship; construction sector is one of the strongest four sectors among the twenty economic sectors (Dang, Low 2011). According to this, construction sector uses the products and services produced by the other many sectors as input and the structures that are the final products of the building activities come to our face as a component of the products and services produced by different sectors. Due to its relationship with other sectors, it is accepted that the growth experienced in construction sector will also trigger the growth in the other sectors and, via this way, contribute to the general economic growth. Furthermore, it 
is assumed that construction sector functions as an important resource of employment in the periods of growth and becomes effective in reducing unemployment.

Turkish construction sector, besides its linkages with the other domestic sectors, also undertakes an important role in international scale. According to the data of Economy Ministry, in the first 9 months of 2014, Turkish contractors undertook the 173 new projects, whose total price is USD 15.2 billion, in 36 countries. Together with these values, beginning from 1972, when the first project was undertaken abroad, to the end of the third quarter of 2014, total values of 7601 projects undertaken in 103 different countries abroad reached the level of USD 292,6 billion. In this context, in the list of the largest 250 international contractors of the world, published by ENR (Engineering News Record), magazine of international construction sector, based on the incomes of the contractors obtained from the activities outside their countries in the previous year, the number of Turkish contractors that are 38 according to 2012 data rose to 42 in the list published August 2014. With this number, Turkey maintained its place in the second rank following China that takes place in the first rank of the list with 62 firms, while US took place in the third rank with 31 firms (TCA 2014, 19).

In this study, it was aimed to analyze the Turkish construction sector from the structural points of view and to present the effect of the developments in the construction sector on some selected macroeconomic indicators. In the structural analysis, the backward and forward linkages with the sectors, with which the construction sector is linked, will be parametrically calculated. Additionally, effects of the sector on macroeconomic indicators that are growth, employment and balance of payments will be identified.

\section{THE RESEARCH METHODOLOGY}

\section{AND THE COURSE OF THE RESEARCH PROCESS}

In the literature, the roles of construction sector in the national economy were handled by many researchers and international agencies. In this context, Strout (1958) and Ball (1881) presented that construction sector had the effect to create employment directly in labor market and indirectly on the other sectors. Park (1989) and Osei (2013) suggested that construction sector had the forward and backward linkages with the other sectors at high level and, therefore, created a high multiplier effect on economy. This situation means that 
construction sector has strong linkages with other sectors of economy. In this context, Bon (1992) determined that construction sector has a dynamic relationship with the sectors, not static. Similarly, Ofori (1990) presented the importance of construction sector for economy and its linkages with other sectors at the high level. According to Field and Ofori (1988), construction sector was the leading sector making the most and the most visible contribution to the growth process.

In the studies carried out on the developing countries (Strassmann 1970; Drewer 1980; Edmonds and Miles 1984; Wells 1986; Polenske and Sivitanides 1990; Wibowo 2009; El-namrouty 2012), it was seen that construction sector had more positive effects on the growth compared to the other sectors and had high level of linkages with the other sectors. In the studies carried out on the developed countries, it was identified that the construction and infrastructure works had a direct effect on the investments and indirect effect on economic growth (Wigren, Wilhelmsson 2007, 449). In a study carried out by Pietroforte and Gregori (2003) on the eight developed countries (Australia, Canada, Denmark, France, Netherland, Germany, Japan, and USA), it was concluded that the role of construction sector in the national economy decreased with every passing day. In the study, carried out by Dlamini (2012), it was identified that there was not a very strong relationship between construction investments and economic growth in the long run; however, in the short run, that construction investments affected the economic growth positively. Tse and Ganesan (1997), using Granger causality test, in a study they carried out on Hong Kong economy, reached the conclusion that the growth in building sector did not increase the national income, conversely, that the increases occurred in the national income increased the investments of construction sector.

Lopes (1998) and Lopes et al. (2002), with moving from the data of 22 years belonging to the 15 developing countries in Sub-Saharan Africa, studied the long run relationship between economic growth and construction investments. According to the results of analysis, a contraction that will be experienced in the investments of construction sector engenders a direct decrease in national income per capita.

Ramachandra and Rameezdeen (2006), in Sri-Lanka economy, with the data belonging to the period of 1980-2004, studied the relationship between construction investments and economic growth, using Granger causality test. According to the results of analysis, they reached the conclusion that there was a one - way causality relationship between construction investments and eco- 
nomic growth and that construction sector positively affected the economic growth. These results have an attribute supporting the view that "investments on construction sector result in growth", obtained in the studies carried out by Hillebrandt (1985), Ofori (1990) and Tiwari (2011). Similarly, in a study carried out by Khan (2008) on Pakistan, it was identified that there was a one way strong relationship between construction sector and general economy and it was reached the conclusion that construction sector was the most important sectors in Pakistan's economic growth.

Choy et al. (2011) analyzed three-ways relationship between construction activities, real estate investments and economic growth. According to the results of analysis, it was identified that there was causality from GDP to real estate investments and from the increase of construction activities to GDP growth. In addition to that, it was reached the conclusion that there was not any causality relationship between real estate investments and construction activities and, in spite of this increase in construction activities led GDP to grow.

Kılıç and Demirbaş (2012), using the data regarding the period of 19802007, in the studies they carried out on Turkey, reached the conclusion that there was a long run relationship between the rate of building expenditures other than public buildings to GDP and GDP growth rate.

Kaya et al. (2013), using the data of the period of 1987-2010, in Turkey, studied the relationship between the building investments of public and private sector and economic growth. According to the results of analysis, it was identified that there was a one-way causality relationship, both from public sector building investments to GDP and from public sector building investments to private sector building investments, with GDP.

\section{CONSTRUCTION SECTOR AND MACROECONOMIC INDICATORS}

Construction sector is a highly comprehensive economic activity arms including especially distinction of construction of building and non-building, also infrastructure investments such as highway, railway, airport, water pipeline, oil pipeline, ports, dams, and bridges. Construction sector carries the attribute of "locomotive of economy" due to the demand to the goods and services produced by over 200 subsectors depending on it (SPO 2010, 2).

Construction sector is a sector adding acceleration and giving a life-line support to economy. This imputation results from, especially the value - added it creates in the period of growth, employment potential, and its input-output 
relationship with a number of sectors (Uzunkaya 2013). The 10 years' general view of Turkish construction sector is summarized by means of Figure 1.

Figure 1. General view of construction sector in Turkey

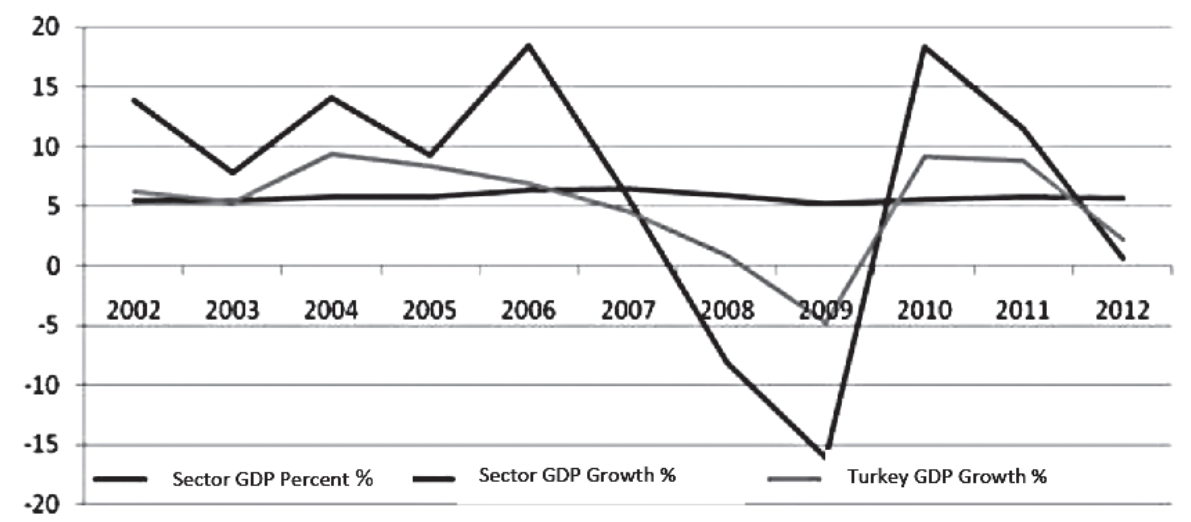

S o u r c e: TSI 2013; TSI 2014; TSI 2015.

According to Figure 1, there is a similar tendency between economic growth and construction sector. Between growth rate of construction sector and growth rate of GDP, there is a high correlation like 0.93 . This identification confirms that the movements of both indicators in the same direction. In addition, while construction sector downsizes more rapidly in the periods of crisis compared to the general economy, in overcoming crisis, it grows more rapidly even if it is delayed compared to the general economy. While construction sector is more rapidly affected from the crisis experienced in 2008, in the other periods, it proportionally grew more compared to economic growth.

In Turkey, construction sector entered the growth trend beginning from 1980s. Especially beginning from 2000s, building expenditures of both public sector and private sector and, in this context, an important part of the increase in GDP resulted from the growth of construction sector. However, albeit the crisis occurring in February 2001 began as a banking crisis, including construction sector in it, it rapidly spread to all sectors and turned into a deep economic crisis (Karg1 2013, 3). After crisis under consideration, also with the effect of international conjuncture, the sector that begins to recover, beginning from 2002, recorded a growth over annual average 7\% (TCA 2011, 16-17). 
As will be understood the data in Figure 1, the investments on construction sector is important to the development of country, because in each stage from a project phase of a building to the phase of completion, the new employment areas are created and this process also continued in the next periods. Thanks to construction sector, accelerating the dam and irrigation projects, infrastructure of agricultural sector, provides the new employment possibilities for the population living in the rural area and accelerate the remigration. Together with the level of income per capita that increases, the welfare level in the rural sectors increase. In Turkey, especially beginning from 2000s, the low and middle income oriented projects implementation of collective housing of TOKI (State Housing Agency) is important in terms of sustainability of the growth in Turkish economy.

Construction sector has an important place in terms of employment. However, from the seasonal point of view, particularly in the winter months, some fluctuations occur in the employment of sector. In Table 1, the sectorial distribution of employment in Turkey and share of construction sector are seen.

Table 1. The sectorial distribution of employment and construction sector

\begin{tabular}{|l|c|c|c|c|c|c|c|c|c|c|}
\hline \hline & \multicolumn{4}{|c|}{ A thousand people } & \multicolumn{5}{c|}{ Percent \% } \\
\cline { 2 - 12 } & Agrclt. & Industry & Cons. & Services & TOTAL & Agrclt. & Industry & Cons. & Services & TOTAL \\
\hline \hline 2004 & 5713 & 3929 & 967 & 9023 & 19632 & 29.1 & 20.0 & 4.9 & 46.0 & 100 \\
\hline 2005 & 5154 & 4183 & 1107 & 9623 & 20067 & 25.7 & 20.8 & 5.5 & 48.0 & 100 \\
\hline 2006 & 4907 & 4283 & 1196 & 10037 & 20423 & 24.0 & 21.0 & 5.9 & 49.1 & 100 \\
\hline 2007 & 4867 & 4314 & 1231 & 10326 & 20738 & 23.5 & 20.8 & 5.9 & 49.8 & 100 \\
\hline 2008 & 5016 & 4440 & 1242 & 10495 & 21194 & 23.7 & 20.9 & 5.9 & 49.5 & 100 \\
\hline 2009 & 5240 & 4079 & 1306 & 10650 & 21277 & 24.6 & 19.2 & 6.1 & 50.1 & 100 \\
\hline 2010 & 5683 & 4496 & 1431 & 10986 & 22594 & 25.2 & 19.9 & 6.3 & 48.6 & 100 \\
\hline 2011 & 6143 & 4704 & 1676 & 11586 & 24110 & 25.5 & 19.5 & 7.0 & 48.1 & 100 \\
\hline 2012 & 6097 & 4751 & 1709 & 12266 & 24821 & 24.6 & 19.1 & 6.9 & 49.4 & 100 \\
\hline $2013 / 9$ & 6370 & 4914 & 1879 & 12646 & 25808 & 24.7 & 19.0 & 7.3 & 49.0 & 100 \\
\hline \hline
\end{tabular}

S o u r c e : TSI 2013; TSI 2014.

According to Table 1, when the data of 2013 are considered, the highest share in total employment belongs to the services sector with $49 \%$. This sec- 
tor is followed by the agricultural sector with $24.7 \%$, industrial sector with $19 \%$, and construction sector with 7.3. However, it is clearly seen that the share of construction sector in the total employment increases with every passing year. In this context, the employment of private sector that was at the level of 967,000 people reached 1.9 million people in 2013 . When the other effects are accepted as fixed, the employment increasing in the summer months and decreasing in the winter months reflects the seasonal structure of sector and its feature including unqualified worker in a significant level. With the effect of global crisis, in parallel with sectorial constriction seen beginning from 2008, the decrease in the sectorial employment experienced in the same year continued until mid-2009. However, the sectorial employment, beginning from the second half of 2009, entered to the rising trend, compared to the same period of the previous year. This trend continued along the years of 2010 and 2011.

In construction sector, besides domestic developments, especially the activities realized through the contracting services have importance in terms of country economies. Construction sector, in Turkish economy, beside the domestic indicators, in the scope of international activities, reached an important position in terms of balance of payments. When it is considered that Turkey has an economy continuously giving foreign trade deficit, the importance of construction sector will increase more and more. In Table 2 , the effect of construction sector on balance of payments is seen.

Table 2. Effect of construction sector on balance of payments

\begin{tabular}{|c|c|c|c|c|c|c|c|c|c|c|c|c|}
\hline \multicolumn{4}{|c|}{$\begin{array}{l}\text { Detailed presentation } \\
\text { of balance of payments }\end{array}$} & \multirow[b]{2}{*}{2004} & \multirow[b]{2}{*}{2005} & \multirow[b]{2}{*}{2006} & \multirow[b]{2}{*}{2007} & \multirow[b]{2}{*}{2008} & \multirow[b]{2}{*}{2009} & \multirow[b]{2}{*}{2010} & \multirow[b]{2}{*}{2011} & \multirow[b]{2}{*}{2012} \\
\hline & (Million USD) & 2002 & 2003 & & & & & & & & & \\
\hline I- & CURRENT ACCOUNT & -626 & -7.6 & -14.2 & -21.5 & -31.8 & -37.8 & -40.4 & -12.2 & -45.5 & -75.1 & -48.5 \\
\hline A. & FOREIGN TRADE BALANCE & -6.3 & -13.5 & -22.7 & -33.1 & -41.1 & -46.9 & -53 & -24.9 & -56.4 & -89.1 & -65.4 \\
\hline B. & SERVICES BALANCES & 7.89 & 10.5 & 13 & 16 & 14 & 13.9 & 18.8 & 18.6 & 16.7 & 20.1 & 22.6 \\
\hline 1. & Transportation & 861 & -523 & -1.1 & -25 & 348 & -420 & 177 & 1.82 & 1.3 & 2.3 & 3.7 \\
\hline 2. & Agriculture & 6.6 & 11.1 & 13.6 & 16.1 & 14.5 & 15.8 & 19.5 & 18.4 & 17.4 & 20.2 & 21.3 \\
\hline 3. & Construction Services & 832 & 682 & 724 & 874 & 879 & 759 & 974 & 1.1 & 859 & 838 & 1 \\
\hline 4. & Insurance Services & & & & & -604 & -885 & -703 & -554 & -541 & -468 & -396 \\
\hline 5. & Financial Services & -400 & -83 & -89 & -41 & -247 & -228 & -133 & -355 & -234 & -690 & -642 \\
\hline
\end{tabular}




\begin{tabular}{|c|c|c|c|c|c|c|c|c|c|c|c|c|}
\hline \multicolumn{4}{|c|}{$\begin{array}{l}\text { Detailed presentation } \\
\text { of balance of payments }\end{array}$} & \multirow[b]{2}{*}{2004} & \multirow[b]{2}{*}{2005} & \multirow[b]{2}{*}{2006} & \multirow[b]{2}{*}{2007} & \multirow[b]{2}{*}{2008} & \multirow[b]{2}{*}{2009} & \multirow[b]{2}{*}{2010} & \multirow[b]{2}{*}{2011} & \multirow[b]{2}{*}{2012} \\
\hline & (Million USD) & 2002 & 2003 & & & & & & & & & \\
\hline 6. & $\begin{array}{l}\text { The other commercial } \\
\text { services }\end{array}$ & -68 & -26 & 129 & -200 & -434 & -821 & -1 & -1.3 & -1.3 & -1.4 & -1.6 \\
\hline 7. & Official services & -566 & -708 & -721 & -874 & -920 & -733 & -778 & -846 & -869 & -1.1 & -965 \\
\hline 8. & The other services & 627 & 79 & 454 & 195 & 495 & 501 & 779 & 312 & 84 & 486 & 282 \\
\hline C. & INCOME BALANCE & -4.6 & -5.6 & -5.6 & -5.8 & -6.7 & -7.1 & -8.4 & -8.3 & -7.2 & -7.8 & -7.2 \\
\hline D. & CURRENT TRANSFERS & 2.4 & 1 & 1.2 & 1.5 & 1.9 & 2.2 & 2.1 & 2.4 & 1.5 & 1.8 & 1.4 \\
\hline II- & $\begin{array}{l}\text { CAPITAL AND FINANCIAL } \\
\text { ACCOUNT }\end{array}$ & 1.4 & 3.1 & 13.4 & 19.5 & 32.1 & 37.3 & 37.4 & 9.3 & 44 & 65.7 & 47.3 \\
\hline 4. & RESERVE ASSETS & -6.2 & -4.1 & -824 & -17.9 & -6.1 & -8 & 1.1 & -111 & -12.8 & 1.8 & -20.8 \\
\hline III- & $\begin{array}{l}\text { NET ERRORS } \\
\text { AND OMISSIONS }\end{array}$ & -758 & 4.5 & 838 & 2 & -228 & 517 & 3 & 2.9 & 1.4 & 9.4 & 1.2 \\
\hline
\end{tabular}

S o u r c e : TCMB 2014.

According to Table 2, the contribution of construction sector providing the input of foreign currency around USD 832 million in 2002 to balance of payments rose to the level of USD 1.029 in 2002. These figures contain the foreign currencies registered to the country transferred by the Turkish contractors realizing contracting services abroad. The other important point is that there is no output of foreign currency via "profit transfers" from the construction sector to abroad (there is no figure of expenditure in the item of building services). According to the data of Economy Ministry, in the first 9 months period of 2014, Turkish contractors undertook 173 new projects accounting for the sum of USD 15.2 billion in 36 countries. Together with these values, from 1972, when the first project was undertaken abroad, to the end of the third quarter of 2014, the total value of 7601 projects undertaken in 103 different countries reached the level of USD 292.6 billion (TCA 2014, 19). More than $90 \%$ of the inputs used by the construction sector are obtained from the domestic. Therefore, while the domestic growth of sector does not create an import press, its foreign growth provides the continuous and permanent input of foreign currency. 


\section{THE OUTCOME OF THE RESEARCH PROCESS AND CONCLUSIONS}

The sector consisting of building and non-building activities is accepted as one of the strongest economic sectors in terms of the inputs it uses and employment it creates. Sector, due to this feature of it, undertakes a key role in transition from the economic recession to the growth and it stands out with the dynamic role it played in the process of economic growth and development, because all of the structures such as the highways, dams, ports, factories, trade centers, hospitals, schools, houses, etc., which are the final outputs of this sector, are qualified as investment goods. These products are not only used by their own functions but also in producing the other goods and services and, thus, in creating the value added. Therefore, as in many developed country, also in Turkey, construction sector is one of the most important sectors producing the investment goods.

Due to the fact that construction sector has a structure incorporating all of these features, in many countries economically experiencing contraction, first of all, increasing the investment expenditures in construction sector, a way of outgoing from this bottleneck is sought, increasing the investment expenditures and, thus, economic recovery is again provided. Construction sector, due to its demand to the goods and services produced by over 200 subsectors depending on it, carries the attribute of "locomotive of economy". Each activity realized in the building sector, due to its relationship with the inputs used in building production process, can affect the other related sectors. Thus, construction sector taking place among the strongest sectors in economy in terms of inputs it uses, due to its relationship with the other sectors and its contribution to employment, undertakes a highly important role, in catching and sustaining the desired economic growth rate (Kılıç, Demirbaş 2012, 85).

Construction sector, with its both forward and backward linkages, is in close relationship with other sectors. Effect of direct backward connection indicates the input rate the construction sector uses from the other sectors for it to produce one unit of good (for construction sector to produce one unit that how many the other sectors should produce) and, in our study it is expressed as (Bg). The sectors, which construction sector has the highest backward linkage and the direct backward coefficients of these sectors take place in Table 3. 
Table 3. Direct backward linkage coefficients (Bg) of construction sector

\begin{tabular}{|l|c|l|}
\hline \hline \multicolumn{1}{|c|}{ Item } & Bg & \multicolumn{1}{c|}{ Sectors } \\
\hline \hline 1 & 9.12 & Main - Iron Steel Industry \\
\hline 2 & 8.20 & Production of the cement, lime, and gypsum \\
\hline 3 & 3.67 & Transportation of highway and pipeline \\
\hline 4 & 3.13 & Manufacture of metal, construction materials, cistern, and steam boiler \\
\hline 5 & 2.86 & Manufacture of ceramic products \\
\hline 6 & 2.61 & Financial Agents and similar activities \\
\hline 7 & 2.29 & Wholesale trade and commercial brokerage \\
\hline 8 & 1.73 & Business of sand, clay, and stone pit \\
\hline 9 & 1.57 & Retailing and the repair of household goods \\
\hline 10 & 1.49 & Manufacture of coke furnace and refined oil products \\
\hline TOTAL 10 & 36.67 & Total Bg for the above 10 sectors \\
\hline TOTAL 97 & 50.60 & Total Bg for 97 sectors \\
\hline
\end{tabular}

S o u r c e: DBT $2008,4$.

According to Table 3, the sector, where construction sector provides the most direct input in its production of one unit, is steel-iron sector. In construction sector, for being able to make 100 units of production, 9.12 units of input are used from steel-iron industry. This sector is followed by the sectors such as cement, lime, gypsum, manufacturing industry, and transportation of highway and pipeline. From 10 sectors taking place in Table 3, 72\% of total direct inputs are met by construction sector $(36.67 / 50.60)$. The rate of the sectorial inputs the sector uses in the total production value is $50.6 \%$.

While direct backward linkage is expressed as a function of production, total backward becomes a function of final demand. In this meaning, when there occurs one unit of variation in the final demand (here, the final demand includes the intermediate demands of sectors), how much variation should occur in the production of the other sector sectors by total backward linkage coefficients and they are expressed as Btg in our study. Here, this effect which can be seen totally is also seen on the basis of single sectors. As a result of the demand increase of 100 units to the construction sector, Btg coefficients indicating how much the production of the other sectors will increase take place in Table 4. 
Table 4. Total backward linkage coefficients of construction sector

\begin{tabular}{|l|c|l|}
\hline \hline \multicolumn{1}{|c|}{ Item } & Btg & \multicolumn{1}{c|}{ Sectors } \\
\hline \hline 1 & 100.08 & Construction \\
\hline 2 & 17.21 & Main iron-steel main industry \\
\hline 3 & 9.36 & Manufacture of cement, lime, and gypsum \\
\hline 4 & 6.32 & Transportation of Highway and Pipeline \\
\hline 5 & 5.45 & Financial Agents and similar activities \\
\hline 6 & 4.49 & Manufacture of coke furnace and refined oil products \\
\hline 7 & 3.97 & Wholesale trade and commercial brokerage \\
\hline 8 & 3.93 & Generation, Transmission, \\
\hline 9 & 3.82 & Manufacture of metal, construction materials, cistern, and steam boiler \\
\hline 10 & 3.07 & main non-iron-steel metal industry \\
\hline TOTAL 10 & 157.69 & Total Btg for the above 10 sectors \\
\hline TOTAL 97 & 199.83 & Total Btg for 97 sectors \\
\hline \hline
\end{tabular}

S o u r c e : DBT 2008, 5.

Construction sector, in case that there is an increase in its final demand, for it to be able to meet the demand of interest, should first of all increase its own production at least in that rate. According to Table 4, when the final demand of the products of sector increased by 100 units, the own production of sector increased by 100.08 units. Beside this, for example iron-steel sector is in the position of increasing the production in the rate of $17.21 \%$ for being able to meet both the demand of input and demand increase to construction products. The main distinction between total backward linkage and direct backward linkage arises from here. In the direct backward linkage (independently from the level of final demand and variation at this level), while the level of technical production, which is necessary for the production of 100 units of construction, is seen; in total backward linkage, as a result of the increase of both this intermediate demand that is "technically" necessary and the final demand of construction sector, the total demand that is necessary to meet the demand (e.g. as a result of construction demand, more iron-steel production; new factory need of more iron-steel production; and the increase in demand of construction sector that is necessary for this) that is affected in "enchaining" way is reflected. When construction sector itself is excluded, in case that the demand to the products 
of construction sector increases by 100 units, in the first nine sectors providing the most input to the sector, a production increase of 57.61 units emerge (157.69 - 100.08). These determinations point out that construction sector has so high backward linkage. When all of 97 sectors are considered, the increase in demand to the construction sector provides a production increase (199.83 $100.08=99.74$ units) at an almost close level to this demand increase. In this context, while the share of construction sector in the national income is around $6.5 \%$, when the other 9 sectors, with which the sector has the highest linkage, are taken into consideration, the shares of discussed sectors in the national income rise to the levels of $38 \%$.

The effect of total forward linkage indicates that, when a variation of one unit appears in the final demand to all sectors how much variations will occur in the production of the relevant sector. Here, it should not be forgotten that the final demand does not include the amounts demanded by the other sectors (intermediate demand) and only defines the amount that remains out of this and is demanded by final consumers from that good. Differently from the effect of total backward linkage, there is not only a final demand increase to the construction sector but also to all of 97 sectors. As a result of demand increase under consideration, how much sectorial productions will increase is expressed as Bi coefficient. Total forward linkages of construction sector are summarized in Table 5.

Table 5. Total forward linkage coefficients of construction sector (Bi)

\begin{tabular}{|l|c|l|}
\hline \hline \multicolumn{1}{|c|}{ SIRA } & Bi & \multicolumn{1}{|c|}{ SECTORS } \\
\hline \hline 1 & 100.08 & Construction \\
\hline 2 & 5.08 & Ownership of house \\
\hline 3 & 1.59 & Educational Services \\
\hline 4 & 1.17 & Hotels, Motels, and the other accommodation places \\
\hline 6 & 0.87 & Manufacture of products of the ground cereal and starch \\
\hline 7 & 0.52 & Restaurant, coffee - house, and eating -drinking places \\
\hline 8 & 0.48 & The other service activities \\
\hline 9 & 0.44 & Retailing and repair of personal and household goods \\
\hline 10 & 0.40 & Health Works and Social Services \\
\hline
\end{tabular}




\begin{tabular}{|l|c|l|}
\hline \hline \multicolumn{1}{|c|}{ SIRA } & \multicolumn{1}{|c|}{ Bi } & \multicolumn{1}{|c|}{ SECTORS } \\
\hline \hline TOTAL 10 & 111.01 & Total Bi for the above 10 items \\
\hline TOTAL 97 & 117.09 & Total Bi for 97 sectors \\
\hline
\end{tabular}

S o u r c e: DBT $2008,7$.

According to Table 5, when it is considered that the final demand increase of construction sector will instigate the demand of construction sector at least in the same sum, the demand of construction sector is affected the most from the demand increase in the ownership of house sector. In this context, in the final demand of sectors, in case that an increase of 100 units for each sector, the production of construction sector increases by 17.09 units for being able to meet this demand. In case of an increase of production of construction sector, a production increase of 5.08 units in the sector of house ownership and, 1.59 units in the sector of educational services occur. When these parameters are taken into consideration, it is seen that the forward linkages of construction sector is weaker compared to its backward linkages. On the other hand, while construction sector, depending on the final demand increase to its own products, increases its production by $17.09 \%$, the production of sectors on which the construction sector depends increases in the rate close to 100\% (99.93\%).

In the framework of determinations expressed above, the development of construction sector should not only be limited by the increase of national income. Also considering the linkages with other sectors, in case that the necessary arrangements are not carried out, the effect of construction sector "to accelerate economy and to stimulate other sectors" will remain limited. The effect of construction sector to stimulate other sectors, in a sense, becomes notable thanks to the projects (e.g. house, building, infrastructure investments toward increasing the production of this sector, rather than the effect occurring in the demand.

In this study, Turkish construction sector has been structurally analyzed and the effect of sector on some selected macroeconomic indicators has been handled. In the structural analyses, the backward and forward linkages of the construction sector with the sectors it is linked have been parametrically examined. In addition, the effect of sector on the growth, employment, and balance of payments among macroeconomic indicators has been analyzed. According to the analyses and assessments carried out, in Turkey, there is a high correlation between the growth rate of construction sector and GDP growth. 
In this context, while both indicators act in the same direction, construction sector downsizes more rapidly compared to the general economy, in going out, even delayed, they grow more rapidly compared to the general economy.

Construction sector, directly or indirectly, has important effects on the labor force market. The share of construction sector in the total employment increases with every passing day. The main sector employment being at the levels of 967 thousand people in 2004, reached 1.9 million of people in 2013.

In terms of balance of payments, construction sector undertakes important roles. The contribution of sector, which provides the input of foreign currency around USD 632 million in 2002, to the balance of payments rose to the levels of USD 1.029 billion in 2012. When foreign contracting services are taken into consideration the importance of sector increase much more. In the first 9 months period of 2014, Turkish contractors undertook 173 new projects, whose sum is USD 15.2 billion, in 36 countries. In this context, when it is considered that the incomes the contractors obtained in the previous years from the activities outside their countries, Turkish contracting firms take place in the second rank in the world, following China.

When the backward linkages of construction sector with the other sectors are examined, it is seen that the sector is linked at the high degree with manufacture of iron-steel, cement, lime, gypsum, etc. and transportation of highway and pipeline. When its backward linkages are taken into consideration, it was identified that the construction sector was affected the most from the increase occurring in the demand of house ownership .This is followed by sector of educational services as well as hotels, motels, and the other accommodation facilities. When both linkages coefficients are considered together, it was seen that the forward linkages of construction sector were weaker compared to their backward linkages.

When all of these conclusions and discussions are considered together, besides the backward and forward connections, in case that the developments in abroad contracting services are carried out in a stable way, construction sector will be one of the most important leading sectors in terms of Turkish economy. Due to these intensive relationships of it with the other sectors, it is considered that a growth or expansion experienced in the construction sector may also stimulate in the other sectors and, with this way, that it can make more contribution to the general economic growth. 


\section{REFERENCES}

Ball R. (1981). Employment created by construction, expenditures. Monthly Labour Review, 104, 38-44.

Bon R. (1992), The future of international construction: secular patterns of growth and decline, Habitat.

Choy C.F., Skitmore M., Runeson G., \& Bridge A. (2011). Property investment, construction and economic growth: the case of Malaysia. In The Asian Conference on Real Estate (ACRE 2011) Sustainable Growth, Management Challenges, 3-5 October 2011, Thistle Johor Bahru, Malaysia.

Dang T.H.G., \& Low S.P. (2011). Role of construction in economic development: review of key concepts in the past 40 years. Habitat International, 35(2011), 118-125.

Dlamini S. (2012), Relationship of Construction Sector to Economic Growth, http:// www.sitsabo.co.za/docs/misc/cib_paper2012.pdf (accessed: 10.02.2013).

SPO (State Planning Organization-Turkey) (2010), Üniversite ve Kamu Araştırmaları Merkezleri, DPT Müsteşarlığı, Ankara.

Drewer S. (1980). Construction and development: a new perspective. Habitat International, 5 (3/4), 395-428.

Edmonds G., \& Miles D. (1984), Foundations for Change: Aspects of Construction Industry in Developing Countries, ITP, London.

Field B., \& Ofori G. (1988). Construction and economic development-a case study. Third World Planning Review, 10(1), 41-50.

Hillebrandt P. (1985), Analysis of the British Construction Industry, Macmillan, London.

Hirschman A.O. (1958), The Strategy of Economic Development, Yale University Press, New Haven, CT.

INTES (2014), İnşaat Sektörü Raporu, Ankara.

Kargi B. (2013). Interaction between the economic growth and the construction industry: a time series analysis on Turkey (2000-2012). Emerging Markets Journal, 3, 20-34. http://dx.doi.org/10.5195/emaj.2013.37 .

Kaya V., Yalçinkaya Ö., \& Hüseyni İ. (2013). Ekonomik büyümede inşaat sektörünün rolü: Türkiye örneği (1987-2010), Atatürk Üniversitesi İktisadi ve İdari Bilimler Dergisi, 27(4), 148-167.

El-namrouty K. (2012). The impact of construction sector on Palestinian economy case study (Gaza strip). American Academic and Scholarly Research Journal, Special issue, 4(5).

Khan R.A. (2008), Role of Construction Sector in Economic Growth: Empirical Evidence from Pakistan Economy, http://www.neduet.edu.pk/ ICCIDCI/Conference\%20Proceedings/Papers/030.pdf (accessed: 10.02.2013).

Kiliç R., \& Demirbaş E. (2012). Türkiye'de kamu inşaat harcamalarının belirleyicileri ile ekonomik büyüme arasındaki ilişki. Akademik Yaklaşım Dergisi, 3(2), 84-97.

Lopes J. (1998). The construction industry and macroeconomy in Subsaharan Africa post 1970. Construction Management and Economics, 16(6), 637-649. http://dx.doi. org/10.1080/014461998371935. 
Lopes J., Ruddock L., \& Riberio F.L. (2002). Investment in construction and economic growth in developing countries. Building Research and Information, 30(3), 152-159. http://dx.doi.org/10.1080/09613210110114028.

Ofori G. (1990), The Construction Industry: Aspects of Its Economics and Management, Singapore University press, Singapore.

Osei V. (2013). The construction industry and its linkages to the Ghanaian economy-polices to improve the sector's performance. International Journal of Development and Economic Sustainability, 1(1), 56-72.

Park S.H. (1989). Linkages between industry and services and their implications for urban employment generation in developing countries. Journal of Development Economics, 30(2), 359-79. http://dx.doi.org/10.1016/0304-3878(89)90009-6.

Pietroforte R., \& Gregori T. (2003). An input-output analysis of the construction sector in highly developed economies. Construction Management and Economics, 21, 319-327. http://dx.doi.org/10.1080/0144619032000056153.

Polenske K., \& Petros S. (1990). Linkages in the construction sector. The Annals of Regional Science, 24 (2), 147-161. http://dx.doi.org/10.1007/bf01579729.

Ramachandra T., \& Rameezdeen R. (2006). Study of the relationship between construction sector and the Sri Lankan economy. Built-Environment-Sri Lanka, 6(2), 50-56.

Strassmann P.(1970). The construction sector in economic development. Scottish Journal of Political Economy, 17(3), 390-410. http://dx.doi.org/10.1111/j.1467-9485.1970. tb00715.x.

Strout, A.M. (1958). Primary employment effects of alternative spending: programs. The Review of Economics and Statistics, 15(4), 319-328. http://dx.doi. org/10.2307/1926334.

TCMB (2014), Ödemeler Dengesi ve İlgili İstatistikler, http://www.tcmb.gov.tr (accessed: 10.10 .2014$)$.

Tiwari A.K. (2011). A causal analysis between construction flows and economic growth: evidence from India. Journal of International Business and Economy, 12(2), 27-42.

DBT (Development Bank of Turkey) (2008), Türkiye'de İnşaat Sektörü Üzerine Bir Değerlendirme, Ekonomik ve Sosyal Araștırmalar Müdürlügü, Ankara.

TCA (Turkish Contractors Association) (2011), 30. Olağan Genel Kurulu Dönem Raporu (Nisan 2008-Nisan 2011), Türkiye Müteahhitler Birliği Yayını, Ankara.

TCA (Turkish Contractors Association) (2014), İnşaat Sektörü Analizi, Türkiye Müteahhitler Birliği Yayını, Ankara.

Tse R.Y.C., \& Ganesan S. (1997). Causal relationship between construction flows and gdp: evidence from Hong Kong. Construction Management and Economics, 15(4), 371-376. http://dx.doi.org/10.1080/014461997372926.

TSI (Turkish Statistical Institute) (2013), Ekonomik Göstergeler 2013-II, Türkiye İstatistik Kurumu Matbaası, Ankara.

TSI (Turkish Statistical Institute) (2014), Hanehalkı İşgücü Araştırması: Bölgesel Sonuçlar 2004-2013, Türkiye İstatistik Kurumu Matbaası, Ankara.

TSI (Turkish Statistical Institute) (2015), Íktisadi Faaliyet Kollarına Göre Cari Fiyatlarla Gayri Safi Yurtiçi Hasıla, www.tuik.gov.tr/PreIstatistikTablo.do?istab_id=992 (accessed: 10.02.2015). 
Uzunkaya M. (2013), Uluslararası Rekabet Edilebilirlik Çerçevesinde Türk İnşaat Sektörünün Yapısal Analizi, İktisadi Sektörler ve Koordinasyon Genel Müdürlügü, Haziran.

Wells J. (1986), The Construction Industry in Developing Countries: Alternative Strategies for Development, Croom Helm, London.

Wibowo M. A. (2009), The Contribution of the Construction Industry to the Economy of Indonesia: A Systemic Approach, http://eprints. undip.ac.id/387/1/Agung_Wibowo. pdf (accessed: 12.01.2013).

Wigren R., \& Wilhelmsson M. (2007). Construction investments and economic growth in Western Europe. Journal of Policy Modeling, 29(3), 429-451. http://dx.doi.org/10.1016/j.jpolmod.2006.10.001. 